\title{
Recent research on the aesthetics of knowledge in science and in religion
}

A $\mathrm{s}$ an introduction to the case studies collected in the current special issue, this review article provides a brief, and by no means exhaustive, overview of research that proves to be relevant to the development of a concept of an aesthetics of knowledge in the academic study of religion and in science and technology studies. Finally, it briefly discusses recent work explicitly addressing the aesthetic entanglement of science and religion.

\section{Introduction: 'aesthetics'}

Nowadays the term 'aesthetics' usually refers to philosophical reflections relevant to art, but in the literature there are also other, broader understandings of the scope of its meaning. Loosely following the heuristic distinction made by Clive Cazeaux in his Continental Aesthetics Reader (2nd edn 2011), we may regard aesthetics as referring (1) to reflections on art and beauty, (2) as generally dealing with bodily and sensory perception in the ancient Greek tradition of aisthesis, or (3) as referring to philosophical approaches which question the divide between a perceiving subject and perceived reality.

Aesthetic approaches in the third sense regard perception, with or without intrinsic cultural connotations, as a primary factor in the construction of knowledge about the world. In the modern period, the philosophical project of Alexander Gottlieb Baumgarten (Aesthetica 1750-58), which was developed further by Immanuel Kant and which defined aesthetics as a 'science of sensitive cognition' (scientia cognitionis sensitivae, paragraph 1), provided the starting point for aesthetic reflections and debates concerned with this third meaning, with some later authors detaching the 'aesthetic' from the 'rational' experience, while others upheld the impossibility of such a distinction, among them the Naturphilosophen of the nineteenth century and the phenomenologists of the early twentieth century (Cazeaux 2011, Jütte 2014). As even this brief sketch shows, the definition of aesthetics was then and still is now no simple matter of word choice, but already carries the implication of some assumptions on the epistemic relevance of sensory perception.

Although in this special issue we do not aim at presenting philosophical reflections, the epistemological implications of speaking of an 'aesthetics of knowledge' have to be spelled out, since this theme is historically entangled with the traditional philosophical distinction between science, religion, and art. The same philosophical traditions which distinguished between an aesthetic and a rational experience related the former to religion and art and the latter to philosophy and science (Grieser 2015b, Meyer 2000). Moreover, they tended to regard the senses as (usually five) well-defined organic functions connecting the mind to the outer world (Jütte 2014). The notion of the five senses as epistemically transparent and culture-independent interfaces to the world established itself in both philosophy and science in the modern period and it was only during the second half of the twentieth century that it came to be variously criticised on the grounds of historical, anthropological and scientific results (Howes 2014). In this period, aesthetics also re-emerged as a philosophical line of inquiry relevant well beyond art theory, critically revising idealist understandings of aesthetics (Welsch 1987 and 2014, Eagleton 1990, Böhme 2001). From the 1990 os onwards, the understanding of aesthetics has continued to develop from being a normative philosophy of art and beauty into 
an analytic concept for the study of culture. In sociology, theorists of modernity highlighted the aesthetic aspects of capitalism and the way class and (self-) perception were entangled in the embodied habitus (Bourdieu 1984). Jacques Rancière focussed on the 'distribution of the sensible' (2010), and a third strand of politico-aesthetic analysis, 'social aesthetics' (Featherstone 1992) and 'everyday aesthetics' (Mandoki 2007), responds to theories of modernity, further developed into an analysis of modern subjectivity as being characterised by an aestheticisation of the self (Reckwitz 2006).

A whole other field that has developed only recently is concerned with the question of how perception can be studied in terms of evolutionary history, and through scientific methods (Rusch and Voland 2013). While neuro-aesthetics and evolutionary theories of art provide valuable knowledge about universal features of perceptual preferences and judgements, the protagonists of the first generation of neuro-aesthetics were mostly occupied with the search for correlations between brain activity and experiences of beauty (Semir Zekri, Ramachandran). More recent projects have started to interrelate knowledge from both the natural sciences and cultural studies and aim to theorise the link between sensations and emotions in evolutionary and sociocultural terms, 'after Darwin' (Menninghaus 2011, Menninghaus et al. 2015).

In the psychology of perception the main paradigms have come to be dominated by neuro-scientific concepts over the last decade, and perception and cognition have also been researched from this angle. An initial impulse to understand perception as an active, organising principle, rather than delivering just 'raw material' for the intellectual capacities, came from Gestalt psychology. It provided a foundation for capturing the interrelation between visual and conceptual 'figurations' of reality (Arnheim 1969: v). This topic - the relationship between language, image perception and cognition - continued to produce models important in cognitive linguistics (such as conceptual blending; Turner and Fauconnier 2002) and for George Lakoff and Mark Johnson's (1980) conceptual metaphor theory (elaborated into a spatial theory of religion by Knott 2005). Perception was no longer understood to be a passive act, represented through the metaphor of mirroring an outward, fixed reality (Rorty 1979); rather, perception came to be seen as an active, constructive process that can be re- and decon- structed in relation to the cultural mechanism in which it is embedded. This turn in the understanding of sensory knowing was fundamental for the development of a bio-cultural approach in aesthetics.

Interestingly, the development of a 'Philosophy in the Flesh' (Lakoff 1999), and of theories focusing explicitly on a somatic understanding of the aesthetic (Shusterman 1989, 2012) rediscover this potential in a moment when art has given up on aesthetics, rejecting its normative claims (Gell 1998, Elkins and Montgomery 2013). The philosopher Mark Johnson provided a clarification of the relation between the two understandings of aesthetics. The focus of traditional aesthetics, Johnson writes, such as aesthetic judgment, beauty, and art 'should be seen as exemplary, intensified instances of the basic aesthetic contours and processes of human meaning-making. In other words, aesthetics is not merely a matter of aesthetic experience and art, but extends further to encompass all of the processes by which we enact meaning through perception, feeling, imagination, and bodily movement' (Johnson 2015: 24).

The broad spectrum of concepts and debates presented here demonstrates that aesthetics, as an intellectual tradition of its own, sheds light on the affective, somatic and sensory aspects of human engagement with its environment. Projects such as Alfonsina Scarinzi's 'Aesthetics and the Embodied Mind' (2015), which radicalise interactionist models of thinking through the senses, make it especially clear that aesthetics provides a resonant forum for the old question concerning how we can account for the role of the senses in human knowledge.

The methodological approach of this special issue is shaped mainly by cultural and historical studies, and it is not our aim to philosophically investigate the connection between aesthetics and knowledge. We would, however, commit ourselves to a notion of knowledge that includes the diversity of modes of knowledge, starting with the work of Michael Polanyi $(1958,1966)$, and continuing with concepts developed in the sociology of knowledge and in cognitive and behavioural studies, as presented above. This position is interested in how these modes are coordinated in societies rather than supporting claims of a hierarchy of knowledge modes, and it includes, importantly, the reflection on what is not known in a society, what is defined as what can be known, and what not, and how societies (and their knowledge systems), deal with 'non-knowledge' 
(Wehling 2015). Either from an analytical or from a phenomenological perspective: we will use the aesthetics of knowledge as a heuristic, and a comparative tool to gain insights into science, religion and the modern cultures they are embedded in. As an introduction to the case studies collected in the special issue in the following two sections we will provide brief, and by no means exhaustive, overviews of research that proves to be relevant to develop a concept of an aesthetics of knowledge in the academic study of religion (section 2) and in science and technology studies (section 3). Finally, section 4 briefly discusses recent work explicitly addressing the aesthetic entanglement of science and religion.

\section{The aesthetics of knowledge and the academic study of religion}

It would be impossible to discuss here all branches of the study of religion that are relevant to the development, or the application of an aesthetics of knowledge. What might be striking for some in the first instance, however, is approaching religion as a knowledge culture at all. What seems to be self-evident for science in the context of its modern function as the source of expert knowledge in democratic societies (even if challenged) does not seem to fit into the narrative of religious ways of knowing becoming 'superfluous' through a progressive explanation of the world through science. Here, the decision to acknowledge the existence of diverse modes of knowledge becomes relevant. Firstly, we can understand religions as knowledge-producing systems: What do I need to know to be a member of a religion? What ritual knowledge is required to perform a religion? How is 'having a religion' related to knowledge about the body, diet, healing? What 'body knowledge, including habits of seeing, sensing and interpretation, (see below) is cultivated within a tradition? Secondly, such an aspect of religious knowledge can be analysed in its multi-layered interactions with other modes of knowledge. A good example of analysing religious modes of knowledge throughout history is the project 'Religious Knowledge in pre-modern Europe (800-1800)', located at the University of Tübingen (Graduate School 1662). Only if we recognise the scope of knowledge related to religious traditions, which is not confined to cognition and content, does it become obvious how, for example, in the popularisation of science religious and scientific modes of knowing interact in many ways, and by no means only in competitive or exclusionary ways.

A third aspect should be mentioned, and this is the role of knowledge about religion in a society, especially when this knowledge is produced by academics. Studying religion(s) in a scientific way needs to be understood as an important element of the history of modernisation (Kippenberg 2002, Brunotte 2017). Looking at religion as a knowledge culture in this way may also help to re-think what we mean when we describe sciences as knowledge cultures. To give only a brief example, recently critical studies concerning the role of 'soft factors' in science have led to the publication of studies on the ways in which sensory skills and intuitive knowledge have to be acquired through training and they have to be cultivated just as much as the intellectual abilities of a researcher or a doctor (Maslen 2015).

In the course of the recent emphasis on the body, media and materiality as key concepts in the study of religion, the relationship between religion and technology has also been re-thought, and this includes how it relates to scientific technologies. While in the early phases of the history of the study of religion technology was seen as an aspect of rationalisation working against religion in the course of modernisation, in the cultural study of religion it has been made clear that religion cannot be studied as a sphere sui generis, separated from developments in politics, economics or technological development. Parallel with the insight that religious history and the history of media have influenced one another in many ways, the understanding of technology and media has also undergone a critical revision. Expanding from an understanding reduced to the progress of technical devices and electronic media, technology and mediation have been identified as aspects of cultural processes and competences: the relevance of the body as a medium has been emphasised, as well as the fundamental role of culturally acquired techniques such as reading and writing, but also storytelling and dancing, or cooking and producing clothes and styles of clothing. Together with the upcoming theorisation of media and technology since the 1960s, and the concept, brought forward by Marshall McLuhan, of humans extending their senses by means of technology and media (1965) (e.g., how telescopes and microscopes and, today, smartphones and computer clouds impact on human perception) it has become obvious that technologies are adapting to human 
needs, but that humans also adapt to the media and technologies they have created.

Religion, in this view, is not viable without the acquisition of cultural techniques, and without giving meaning to, sacralising and making use of technology. Specific attention has been given to the relationships between image and text, and what kinds of knowledge they create, but also to the engagement of humans with objects (Meyer and Houtman 2012). This includes engagement with scientific techniques, practices and objects and how they find their place in religious practice, especially in nineteenth-century practices of spiritualism and occultism; for example the use of technological devices and measurement instruments in spiritual séances (for the work of Stolow see section 4, below). More specifically, the point has been made that religious systems need to solve the 'problem of presence' (Engelke 2007), meaning that they need to manifest absent realities by means of media and strategies of persuasion. Consequently, the status of 'man-made' media and what makes credible things and experiences that are 'not made by human hands' (van de Port 2011) is an important consideration when studying what keeps religions persuasive, and what distinguishes different ways of relating aesthetics and knowledge.

Arguing in a comparable framework, many of the publications contributing to the newly-emerging approach of an aesthetics of religion thematise the wide-ranging dimension of studying, as well as producing, 'sensory processes of knowing. In several introductions and overviews (Wilke and Moebus 2011, Traut and Wilke 2015, Grieser 2015b, Grieser and Johnston 2017) the authors emphasise the importance of considering sensory knowledge as an element of religious practice and communication; but they also show that an aesthetic approach presents challenges for the methodology of collecting nontextual data, for the representation of sensory data, for theorising and interpreting them, and for ways to train our own perceptual skills - for example, when studying the religious usage of sound, movement or scent. A second emphasis lies on the bridge-building between bio-somatic and cognitive aspects of religious practice, on the one hand, and the cultural cultivation of the senses and the perceptual habits and orders of establishing religious knowledge cultures, on the other (Mohr 2005). We cannot elaborate on the growing field of a cognitive science of religion here, but applying the results of cognitive psychology and the psychology of perception is closely related to what is seen as a foundation for understanding how humans 'know through their senses', and how this is realised in religious and scientific practices (see Geertz 2014 for an excellent overview).

In a comparable way, 'imagination' has been conceptualised as a physiological ability that is, at the same time, historically and sociallly cultivated (Traut and Wilke 2015). In contrast to an understanding of imagination as fantasy, or 'making-up' things, it is assumed that imagining requires the ability of decoupling from actual stimuli; we can imagine a cat, a smell, a yesterday in representations and as an 'offlinecognition'. Applied to religion, the authors demonstrate the relevance of such bio-cultural approaches by showing that religion can be understood as a systematic way of cultivating the human imagination so that imaginary worlds - virtual realities, if we like - become real to people, and simultaneously make changes to the first-order reality people inhabit, and to the attitudes towards this reality that they share with other people and their respective attitudes. Another example of this approach is a special issue on religion and museums, and how knowledge cultures are both biologically anchored and deeply intertwined with a long history - in this case a colonial history - of collecting, exhibiting, and shifting objects and people from the sphere of religion into the spheres of academic classifications and objects of art (Kugele and Wilkens 2011). The mode of museality that emerged from these practices is relevant to this day, reverberating in the Buddha figures which are to be seen on the shelves of Western living rooms and garden centres. Core themes are also how to assess and develop modes of 'body knowledge', and why the history of the study of religion is characterised by a neglect of, as well as a fascination with, the body (Koch 2011 and 2016; a special issue of Paragrana 2016, on 'body knowledge' ). Landmark examples of further exploration are studies that include specifically religious concepts of sensing phenomena or qualities deemed non-empirical, paranormal or pertaining to 'the sixth sense', or 'subtle bodies', such as clairvoyance or magnetic forces (Johnston and Samuel 2013).

Finally, from the large body of work concerned with the relationship between science and religion, some innovative studies on science and religion in modernity must be mentioned here because they provide a basis for our reflections on the aesthetics of knowledge. For the study of religion perspective 
on the 'science-religion-art' nexus, two approaches have become seminal. The first of these is an understanding of the three constituent spheres of this nexus as elements of a larger European scenario of a 'double pluralism', a view originating from a project that regards the specific constellation of European religious history as the outcome of a high density of religious and non-religious 'offers' of meaning-making and interpretive ideologies (Gladigow 1995). This project was generated as a corrective to grand narratives about the 'Christian occident' or about a linear development of modernisation as a replacement of religion through a steadily progressing scientific, rationalistic world-view. In contrast to this view, the project has demonstrated that the admitted dominance of Christianity in Europe has led to specific constellations of 'accompanying alternatives' (philosophy, esotericism, heresies, art and literature) and competitions (the diverse formations of Christianity, as well as competing religious and non-religious ideologies and world-views). The other debate that has shaped the discussion, from the study of religion perspective, is the critical revision of secularisation theories, including the acknowledgement of a more complex entanglement of religion and science than secularisation theories suggest, and of a diversification of both spheres, and how they are related to processes of rationalisation or aestheticisation of culture.

Both positions make clear that it is through differentiation processes that a shift takes place in the landscape of meaning-making: it becomes possible to search for meaning and meaningful experience in art and literature, and in the sciences, and functions previously fulfilled by religion have been taken on - sociologically speaking - by other sub-systems of society. As Burhard Gladigow writes:

Via the medium of popularization [the sciences] satisfy newly-emerging needs for meaning - or, in special cases, programmatically create meaning themselves. The production of meaning (Sinnstiftung) through popularization is a field in the recent history of religion which has not yet been explored, and it is probably one of the most important ones. (Gladigow 1995: 36, translation from German by the author)

From this early and programmatic vantage point, and in conversation with post-colonial perspectives on history (Harrison 2015), scholars of religion have deconstructed the concepts of religion and science, including their grounding in European history as religio and scientia, as part of the history of the religious and the secular. Especially in the field of esotericism, this perspective has been pursued by criticising and complementing it with the aspects of power, of mechanisms of inclusion and exclusion of knowledge and of the links between modernisation narratives and the role of religion and science within them (Hammer 2004, Stuckrad 2010, Hanegraaff 2012, Asprem 2014). The role of aesthetics in the rise of scientific knowledge as the dominant provider of the modern secular world-view has been addressed, but not elaborated upon by Kocku von Stuckrad (2014), who points to the celebration of the beauty of nature as 'art forms' (in the work of biologist Ernst Haeckel). Von Stuckrad builds upon, yet critically adds a discursive understanding to, earlier work on the 'world-view-isation of science' through an aestheticisation of science in popular-science communication (Daum 2002). A handbook project on relating religion and science as cultural practices provides an alternative to many other handbooks on the topic (Hammer and Lewis 2011). It analyses ideological struggles from the study of religion perspective rather than engaging in them, and in this way questions the prevalent model of competition or reconciliation. For all of these approaches it is central to see knowledge as a formative process, and to acknowledge that this process includes the aspects of sensing, feeling and imagining.

\section{The aesthetics of knowledge in science and technology studies}

The cultural sphere named 'science' emerged during the nineteenth century in a process which went hand in hand with historical-philosophical reflections defining its identity in opposition to other modes of perceiving, questioning and/or explaining natural phenomena, such as religion, natural philosophy and art (Golinski 2005, Nye 2003, Steinle 2009). These efforts took very different, and at times not mutually compatible directions, but they usually shared the assumption that 'scientific knowledge', however defined, might claim a privileged epistemic status which set it apart not only from religious belief, but also from all other prevailing convictions in academic disciplines and everyday life. As shown by Lorraine Daston and Peter Galison (2007), a very important ideal which emerged in this context was that of (sci- 
entific) 'objectivity', according to which scientific knowledge has universal validity and is independent of contingent, 'subjective' factors, such as the various specific methods by which it is made accessible to the senses. Daston and Galison discuss at length how the development of a 'mechanical objectivity' linked to instrumental and conceptual techniques of recording phenomena (standardised measurement units and procedures, self-inscribing apparatuses, photography) was an essential component in the emergence of the ideals and practices of modern science (ibid. 115-90).

By the early twentieth century it was widely assumed that scientific knowledge had a core, which could, at least in principle, be detached from its sensually-perceivable representations, from the sensations and emotions of the historical actors who produced and used it, and from the cultural-historical constellations in which it was embedded. Although no agreement could be reached on how exactly this conviction might be justified, the assumption that scientific knowledge has a special epistemic status lived on, and among scientists and philosophers of science it still continues to dominate scientific discourse (Cartwright et al. 2003, Nye 2003). Against this background, the history of science might seem to have the task of reconstructing how nuggets of scientific knowledge came to be 'discovered' in various ages, often through long detours, while the aim of the philosophy of science might appear to be the formulation of descriptive or normative criteria for what is and what is not scientific knowledge (Golinski 2005). Until the middle of the twentieth century, historians and philosophers of science, who were often also scientists, for the most part shared the assumption that science is 'objective' and this assumption accordingly shaped their historical and philosophical researches. Consequently, up until the 1960s, the aesthetics of scientific knowledge, in all of its possible meanings concerning an aesthetic appraisal of knowledge, of the ways in which knowledge claims are made sensually perceivable, and of the role of sensual perception in scientific practice, was a subject largely marginalised by philosophers and historians of science (Golinski 2005, Frigg and Nguyen 2016, McAllister 1990). While earlier philosophers of science had often sought to ground the special status of science on its empirical connection, later authors shifted their focus to scientific theories, regarding mathematical structures as privileged means of 'objective', 'rational' expression.
Although the history of science provides ample evidence that aesthetic considerations do play a role in shaping scientific knowledge, an (alleged) distinction between a 'context of discovery' and 'context of justification' was often used to relegate the epistemic role of aesthetic considerations to the former, claiming that 'justified' scientific knowledge takes the form of a set of statements whose meaning is independent of the specific means with which it is expressed (Hoyningen-Huene 1987). Eventually, during the second half of the twentieth century, both this distinction and the notion that scientific knowledge is different from other epistemic constructs became subject to an increasingly intense critique (Schickore 2006). At that time, several currents of thought started questioning the idea of scientific knowledge as a construct fundamentally independent of sociocultural, psychological, economical or political factors (Golinski 2005). Among the most prominent names associated with early challenges to the special epistemic status of science are Ludwig Fleck (1935), Michael Polanyi (1958), Thomas Kuhn (1962) and Paul Feyerabend (1975). Their work prompted reflections and reactions which later combined with other critical currents of thought not originally dealing with science, such as Jacques Derrida's critique of 'Western logocentrism' (Derrida 1967), the media theories of Marshall McLuhan (1965), Vilém Flusser (1983) and Friedrich Kittler (1995) and, later on, cultural, philosophical and physiological studies on embodied cognition (Johnson 2008, Lakoff and Núñez 2000, Varela et al. 1996).

In the context of this broader spectrum of multiformed critiques and counter-critiques, the issue of the epistemic relevance of aesthetics in the sciences was also raised. It is not possible to disentangle the many perspectives, motivations and backgrounds from which the subject was approached, both from each other and from their broader cultural and historical contexts, and here only a handful of exemplary developments will be discussed. Only a few authors employed the term 'aesthetics' to describe their approach, and the choice made here on which results are relevant to our theme are to a certain extent arbitrary, but the best effort has been made to offer a short but comprehensive overview of the research landscape. To this end we will distinguish, as an initial approximation, four lines of research which are engaged with what we term the aesthetics of scientific knowledge. The first question, 
which has attracted much attention on the part of historians and sociologists of science, has been the way in which the material, performative experiences of the construction and consumption of scientific knowledge (e.g. building and using instruments, performing experiments, recording outcomes in different forms, looking at graphs and diagrams) could constitutively shape it. This question has been dealt with both at the level of individuals or small groups of researchers sharing laboratory experiences, as well as from the point of view of how scientific 'facts' are authoritatively established within the broader community and beyond it. A second line of inquiry has been to focus on the sensually-perceivable products of scientific research, in particular images, asking how they aesthetically signify, both within and outside of the scientific community, how they relate to the aesthetic cultures of their time, and whether they may be associated to specific forms of visual reasoning. These investigations often combine methods from art history, cultural studies, media theory and philosophy and are usually less interested in reconstructing historical or sociological constellations than in formulating hypotheses on the nature and epistemic dynamics of (scientific) imagery.

Although studies of visualisations often also ask how visual perception is culturally shaped, it is useful to distinguish a third direction of cultural-historical research which concentrates on the way perception and the body have been conceptualised and manipulated in various ages and contexts, and in particular with reference to the development of medicine and of life and social sciences. A fourth focus of research relevant for the aesthetics of scientific knowledge comprises explicit statements by scientists and nonscientists on the subject, such as the judgements of beauty or ugliness often found in scientific writing and reflections on the relationship between science and art.

\section{Materiality, performativity and the representation of scientific knowledge}

From the 1980s onwards, the focus of historical and philosophical research on science moved away from theories and towards experimental practices, leading to an appreciation of the epistemic role of materiality, perception, tacit knowledge and representation (Gooding, Pinch and Schaffer 1989, Hacking 1983, Latour and Woolgar 1986, Lynch and Woolgar 1988, Shapin and Schaffer 1985). Among the many his- torians and philosophers of science who provided significant case studies on this subject, Bruno Latour made an important contribution with his highly influential notion of 'immutable mobiles'; that is to say, stable knowledge media such as texts, images or maps, which work as means both to sensually represent Western scientific knowledge and to establish its authority (Latour and Woolgar 1987, Latour 1990). Of particular relevance also has been the work by David Turnbull on the role of map-making in the construction of knowledge and power relationships (Turnbull and Watson 1989). Andrew Pickering argued that scientific knowledge manifests itself only when human intentions go through 'the mangle of practice, thus making materiality and performativity the core of the scientific enterprise (Pickering 1995). Very influential in the history and philosophy of science was also Peter Galison's suggestion that, within the single discipline of microphysics, different 'material cultures' may coexist, because the practices and ideals of physicists are constitutively shaped by the specific kinds of instruments they employ in this case particle counters and track detectors which present knowledge by means of radically different aesthetic experiences (Galison 1997). Finally, even mathematical knowledge cannot be seen to be a disembodied, abstract collection of rules and concepts, but is fundamentally shaped by templates from bodily performance and perception, as well as by culture (Lakoff and Núñez 2000, Rotman 1993).

The works quoted above have combined the disciplines of history, philosophy, sociology and anthropology, and in different ways have demonstrated that no clear-cut distinction can be made between the 'content' of science and the aesthetic practices involved in its production and communication. In this context, the question of scientific representation has emerged as a productive locus of interdisciplinary exchange. An early, highly influential collection of essays on 'Representation in scientific practice' was edited by Michael Lynch and Steven Woolgar (1988, and extended edn 1990). On the basis of a series of case studies, the notion of representation in science was problematised in explicit contrast to the traditional ideal of objectivity. For example, Lynch in his paper explained how experimental results in the life sciences are 'mathematized' by a series of standardised practices of visualisation (Lynch 1988). In 2014 Lynch and Woolgar were joined by Caroline Coopmans and Janet Vertesi for a volume on 'Representation in 
scientific practice revisited' (Coopmans et al. 2014), this time also giving prominence to the issue of materiality, which had in the meantime become an additional focus of the discussion about scientific knowledge and its representations.

The material and performative aspects in the construction of scientific knowledge have been studied from a more philosophical and media-theoretical perspective in the collection Inscribing Science: Scientific Texts and the Materiality of Communication edited by Timothy Lenoir (1998), who explicitly quoted Derrida's writings as a starting point for the volume. The interest in scientific representation also included a consideration of the role of language and verbal metaphors in science, a theme which had already been studied by Hans Blumenberg (Borck 2013), and which is particularly relevant for the life sciences (Brandt 2004, Kay 2000). Scholars from narratology and literary studies have also started appreciating how scientific texts, diagrams or images may employ narrative strategies both to convey knowledge and to establish authority claims (Azzouni et al. 2015, Blume et al. 2015, Brandt 2009, Doxiades and Mazur 2012). In the English-speaking academic community a whole field of the 'rhetoric of science' has developed in recent decades to investigate the communication techniques through which scientific discourse is constructed, both within and outside of the academic community (Gross 1990). The range of these investigations is very broad, spanning sociological, philosophical, literary and historical contributions, and most of them help to dispel the prejudice that scientific communication can be clearly distinguished in its form from poetic, artistic expressions.

\section{Scientific visualisation}

Among the different modes of aesthetic representations of scientific knowledge, visualisation has been without doubt the one which has received most attention. In recent decades a number of interdisciplinary essay collections have appeared which endeavour to explore the role of images in science from different perspectives (Adelmann et al. 2009, Frappier et al. 2013, Halpern 2014, Hessler and Mersch 2009a, Hinterwaldner and Buschhaus 2006, Heintz and Huber 2001, Pauwels 2006). These studies are careful to underline that visualisation should not be taken as an absolute category to be sharply distinguished from other perceptual and medial strategies, but rather can be viewed as a case study for better understanding representational practices in science. In the introduction to Luc Pauwels's edited volume Visual Cultures of Science: Rethinking Representational Practices in Knowledge Building and Science Communication (2006) we read:

The issue of representation touches upon the very essence of all scientific activity. What is known and passed on as science is the result of a series of representational practices. Visual, verbal, numeric and other types of representations are used in all sciences and in various types of scientific discourses. ... Visual representations are not to be considered as mere addons or ways to popularize a complex reasoning; they are an essential part of scientific discourse. (Pauwels 2006: 8)

In a similar vein, the German historian of science Olaf Breidbach focused on images to investigate the historical epistemology of scientific perception (Breidbach 1997, 2005). Breidbach explicitly spoke of an aesthetics of knowledge, and in the last paragraph of his monograph Bilder des Wissens. Zur Kulturgeschichte der wissenschaftlichen Wahrnehmung (2005) emphasised how the focus on perception in scientific practice provides a means for investigating its deep connections to the cultures of the time:

Seeing - and therefore observing - must accordingly be discussed in context of a theory of aesthetics. Sciences and experiments have to be studied taking into account such a theory. Scientific observation does not follow from the necessities of experimenting, but rather a premise and fundamental condition of any experiment. The experiment is rather the crystallisation of a program of observation, which in experiment has bound itself to a code of conduct, a code which can eventually even crystallize into apparatuses. Therefore, observation does not separate science from the culture in which it must be understood. Observation understands science as part of a culture of perception in whose context also this specific science has to be described. (Breidbach 2005: 187). ${ }^{1}$

1 'Sehen - und damit das Beobachten - ist entsprechend umfassend, im Rahmen einer Thorie der 
Some scholars, especially within the Germanspeaking community, have focused specifically on images because of their background in art history or visual media studies, and have attempted to develop a science of images (Bildwissenschaft) dealing with the special epistemic role of visualisation in early modern and modern practices (Bildwelten des Wissens 2003-17, Bredecamp et al. 2015, Krämer 2016). Looking at images from this broader perspective, rather then by focusing on their immediate scientific context, it becomes easier to assess the way in which they relate to the visual cultures of their time and tentatively reconstruct the creative and aesthetic experiences linked to their production and consumption. In this spirit, the essay collection Picturing Science, Producing Art edited by Caroline Jones and Peter Galison (1998a) has endeavoured to capture the cultural-historical constructions of boundaries between images of 'art' and 'science', asking: 'What are the conditions under which objects become visible in culture, and in what manner are such visibilities characterised as "science" or "art?"' (Jones and Galison 1998b: 1).

Besides the interest in scientific images as cultural products, there have also been attempts to somehow characterise 'visual reasoning' in the sciences, most prominently Arthur Miller's monograph on the role of visual thinking in the development of quantum physics (Miller 1986). In their edited essay collection Die Logik des Bildlichen ('The Logic of the Visual', 2009), Martina Hessler and Dieter Mersch combine the various goals of endeavouring to reconstruct a logic of the visual which finds special expression in scientific images, graphs or diagrams, but is not limited to them (Hessler and Mersch 2009a). In

Ästhetik zu thematisieren. Die Wissenschaften und auch das Experiment sind in solch einer Theorie $\mathrm{zu}$ verorten. Das wissenschaftliche Beobachten ist kein Desiderat des Experimentellen. Es ist die Voraussetzung und die Grundbedingung jedes Experimentes. Das Experiment ist Kondensat eines Beobachtungsprogramms, das sich im Experiment an einen Kodex gebunden hat, der sich gegebenfalls sogar in Apparaturen kondensiert. Die Beobachtung grenzt die Wissenschaft somit nicht aus der Kultur aus, in der sie zu begreifen ist. Die Beobachtung begreift die Wissenschaft als Teil einer Kultur des Wahrnehmens, in der folglich auch diese Wissenschaft zu beschreiben ist. (Breidbach 2005: 187, English translation by the authors) their long introduction to the volume, Hessler and Mersch provide an overview of a broad range of philosophical, cultural- and media-theoretical questions and remarks that are potentially relevant to the logic of the visual (Hessler and Mersch 2009b). They conclude with a section in which they argue that 'aesthetic activity' (aesthstisches Handeln) could be regarded as a constitutive aspect of scientific practice. Finally, engineering, too, has been a source of case studies for investigating visual reasoning (Frappier $e t$ al. 2013). The studies quoted above have brought to light the variety of phenomena and questions which may be subsumed under terms such as 'image, 'visual' or 'sight', and have shown how difficult, if not impossible, it is to pinpoint a distinction between seeing and other sensual experiences, with the traditional notion of the 'five senses' being questioned.

\section{Science and the senses}

The studies of scientific visualisation have shown how scientific reality is constructed as an objective and rational referent by means of a broad range of hybrid strategies involving cultural and psychological elements, which are later airbrushed out of the picture. These results are of importance for the aesthetics of knowledge not only because they bring the body and the senses back into the picture, but also because they equally apply to scientific notions of the body and of sense perception, which are culturally and scientifically constructed. A number of historical and anthropological investigations have shown how much both academic and everyday reflections on bodies and perception are culturally dependent and especially shaped by the technological environment (Alberti 2016, Classen 2014). In his introduction to the sixth volume of the Cultural History of the Senses, which is devoted to the 'modern age', David Howes offers an overview of the rise of historical and anthropological studies on the cultural construction of bodies and perception, including the pioneering work by William F. Bynum and Roy Porter on Medicine and the Five Senses (1994) (Howes 2014). Within this broader cultural-historical and anthropological research direction the traditional narrative of scientific instruments as enhancing, extending or replacing the senses was deconstructed to show how the emergence of instrumental practice actually entailed a redefinition, and often a systematic devaluation of sensory experience, while at the same time the scientific investigation of bodies and perception constructed biological and 
neurological 'facts', allegedly free of cultural influences (Roberts 2014, Jütte 2014).

Theories in the humanities according to which, in the early modern period, sight gained in status with respect to the other senses have also been criticised as the results of a fixation on literary sources which were biased towards seeing and literacy, although it remains controversial how far sensory experiences of the past can be reconstructed at all on the basis of extant sources (Smith 2007). Since the last decades of the twentieth century, new results in physiology and psychology have challenged scientific views on perception which had been valid since the nineteenth century, but these results, too, can hardly be seen as providing unbiased information on the 'natural' sensorium, since they are both empirically and conceptually shaped by new technologies, and in particular by computers and informatics (Nudds 2014). This is a circumstance which should be critically kept in mind by scholars of the humanities when making use of old and new scientific results on perception and embodied cognition, as has become increasingly common. Finally, the role of the senses in today's scientific practice has recently attracted attention both within science studies and among scientists, resulting in an issue of Science, Technology and Innovation Studies on 'The Five Senses of Science' (Burri et al. 2011) and one of Current Opinion in Chemical Biology on the role of the aesthetic experience in that discipline (Ginsberg 2012).

\section{Aesthetic judgement}

Although is it certainly true that the aesthetics of scientific knowledge cannot be reduced to the study of what scientists state about the beauty or ugliness of their research objects, there is no doubt that such aesthetic judgements are a constant component of both popular and academic scientific writing. As such, they deserve to be investigated and related to the broader context of scientific practice, in particular since, at least in some areas of science, references to the 'beauty' and 'truth' of theories have today become so common as to be a subject of discussion also among scientists (De Regt 2002). Although the role of aesthetic judgement in science has received less attention than have visualisation and representation practices, in recent years some works have appeared on the subject. The philosopher James McAllister devoted a series of papers to the subject (McAllister 1989, 1996, 2013), and edited a special issue of
International Studies of the Philosophy of Science to which various philosophers and scientists contributed (McAllister 2002). A collection of a broad range of case studies on the relationship between art and science was edited by Alfred Tauber (1996), and among the subjects treated is the role of formalisation in modernist art and twentieth-century sciences (Chevalley 1996), as well as how artistic traditions may shape the way in which astronomers visualise the data they collect (Lynch and Edgerton 1996).

A final, general remark is in order regarding the present state of research on the aesthetics of knowledge in science. Despite the great amount of work done and results achieved in recent decades, the theme has received very little attention within the philosophy of science, and this circumstance can be, at least in part, linked to the aftermath of the socalled 'science wars' of the late 1980 os and 1990s. In those years, a series of increasingly harsh and indiscriminate attacks by scientists, especially physicists, took place against new directions in science studies, which the scientists regarded as aiming at discrediting science as a 'mere' construct. It is not possible to discuss here the details and the cultural, political and economical context of these debates (Ross 1996), but one of its outcomes was a split within the humanities. Philosophers of science, especially those working in the analytical tradition, aligned themselves with the scientists' views and from then on avoided any line of research which questione the privileged, epistemic status of scientific knowledge, such as the issue of the epistemic relevance of aesthetic factors (Schickore 2017). Historians and sociologists, on the other hand, often avoided conflict with philosophers and scientists by shifting their focus away from the exact sciences and towards less problematic subjects, such as the life sciences or institutional dynamics.

Only very recently have some philosophers of science again started taking up subjects such as the epistemic relevance of aesthetics, although they have often done so while largely ignoring the results produced in recent decades outside of their community. One example is the volume on Ästhetik in der Wissenschaft ('Aesthetics in Science') edited by Wolfgang Krohn in 2006, where the constitutive role of aesthetic factors in shaping science is investigated almost without reference to the multitude of results of the previous decades and with the apologetic remark that 'evidently this approach displays constructivistic traits' (offensichtlich besitzt ein solcher Ansatz kon- 
struktivistische Züge, ibid. 4). It is to be hoped that in the coming years the interdisciplinary dialogue on this and similar subjects will be reopened.

\section{Science, religion, aesthetics}

As the overview in the previous section shows, science and technology studies on the aesthetics of scientific knowledge have often addressed the relationship between scientific and artistic representation in the visual and literary domains, but rarely the connection between scientific and religious aesthetics. This gap may be linked to the traditional approach to the relationship between science and religion which frames it in terms of 'compatibility' or 'exclusion', as already discussed in the editorial preface to this special issue (Brooke et al. 2001, Ferngren et al. 2000, Moore 1992). The few existing investigations of the aesthetics of knowledge in science and religion focus on pre-modern or early-modern contexts (Daston and Park 2001, Göttler and Neuber 2007, Morus 2011, Smith 2012). A notable exception has been the exhibition and accompanying catalogue Iconoclash, curated by Bruno Latour and Peter Weibel (2002), which highlighted the 'dilemma of representation' in the Western world by means of images from religion, science and art:

The exhibit aims to display, in a systematic confrontation, three great clashes about representation - about its necessity, sanctity, and power - in the domains of science, art, and religion.... Instead of mocking once more those who produce images or instead of being simply furious against those who destroy them, the show aims at placing the viewer in this quandary: "We cannot do without representation. If only we could do without representation". Monotheist religions, scientific theories, contemporary arts, not to forget political theories, have all struggled with this contradictory urge of producing and also destroying representations, images and emblems of all sorts. Through many works of ancient, modern and contemporary arts, through many scientific instruments, the show will fathom that quandary which has been so important for the self-understanding of the Western world. (Iconoclash Exhibition website)
While Iconoclash primarily employed the comparative study of science, art and religion to gain new insights on images and image-making, one of the editors of the special issue at hand here has suggested that there are rhetorical and structural similarities between the religious narratives, especially myths, and some theoretical constructs which have appeared in high-energy physics since the 1960s, in particular the notion of 'spontaneous symmetry breaking' (Borrelli 2012, 2015a) and 'naturalness' (Borrelli 2015b). A very recent addition to the field is the volume Aesthetics of Universal Knowledge (2017), edited by Simon Schaffer, John Tresch and Pasquale Gagliardi, which contains the results of a broad interdisciplinary dialogue which took place in Venice on the theme 'Re-visioning the World: Myths of Universal Knowledge and Aesthetics of Global Imaging' under the sponsorship of the Cini Foundation and involving experts from various humanistic and scientific disciplines. In the volume the relationship between religious and scientific aesthetics is explicitly addressed by John Tresch in his study of 'cosmograms' from the nineteenth century to the present day (Tresch 2017), but other papers in the volume also offer case studies which are of relevance for gaining insights into the aesthetic relationship between scientific and religious knowing.

While the STS academy has paid little heed to the aesthetic connections between science and religion, scholars with a background in religious studies have shown more, albeit still limited, interest. The essay collection Deus in Machina: Religion, Technology, and the Things in Between (Stolow 2013) uses a focus on materiality and mediatization to learn more about the role of religion and technology in modern culture. Explicitly building upon the works in religion and science studies which have brought to light the epistemic relevance of media and materiality, the essays in the collection ask and answer, from different perspectives, the question

Is it still useful-is it still even possible-to imagine that religion and technology can be parcelled out as two discrete dimensions of the cosmos? What is at stake in the provocation of this book's title to locate "god in the machine?" Who has the authority to weigh those stakes? What might be gained or lost once religious and technological things are allowed to mingle promiscuously with one another? (Stolow 2013: 3) 
Deus in Machina focuses on the entanglement of religion, technology and media, but does not explicitly address the issue of scientific aesthetics (see above, on esotericism and science, where we point out that an overlap area emerges when occult practices and spiritualism of the nineteenth century can be observed to have used scientific instruments, experimental settings and scientific reasoning). The similarities between religious and scientific aesthetics have instead been noted by Gregory Schrempp, who convincingly argues that popular-science writers employ narrative techniques characteristic of mythology (Schrempp 2012, 2016). Schrempp focuses on popular-science writing, and stops short of claiming that styles of mythological narration also have a place within academic science. This insight needs to be read against the backdrop of the wider 'rhetorical turn' that took place in the 1990s when, firstly, history writing was scrutinised as being rhetorically constructed and, secondly, the dependence of science communication on figuration, metaphors and rhetorical means was brought into the debate not only in popular science, but in all areas of communication that use verbal language (Gross 2006).

As with aesthetic critiques, the analysis of rhetorical forms within science was difficult to liberate from the misunderstanding that 'constructionism' would discredit the value of scientific knowledge production; therefore, separating 'the sacred from the profane' - meaning separating religious from scientific language - was not only part of the analysis, but also part of a rhetoric of defence: 'Rhetoric is, after all, a shabby little weasel word in most circles, and science is a god-term; putting the two words together, only a slim little proposition between them, was not an act for the faint of a pen or a keyboard' (Harris 1991: 282; Harris 1997; for an overview of the relationship between religion and rhetoric see Grieser 2015C).

Another aspect is addressed in a debate that only indirectly refers to aesthetics, yet contains important arguments about the possibilities of distinguishing conditions of sensing and knowing in religious and scientific knowledge practice. Crystallising in a discussion published as a special issue on 'Religious Studies as a Scientific Discipline: A Delusion?' (Religio: Revue pro religionistiku, 20(1), 2012), scholars representing the cognitive study of religion discuss the 'hardwiredness' of religion and 'Why religion is natural, and science is not' (McCauley 2012). This position stimulated a debate on criteria that would distinguish religious from scientific knowledge by ways of cognitive preferences. Religion, in this view, is a specific mode of dealing with the necessity, or ability to make sense of the environment through figuration, imagination and interpretation. Religion responds better to the preferred modes of human cognition and imagination than scientific thinking does, and so scientific thinking will always be in a weaker position, because it is an effort to undermine the evolutionary preferences of the brain. Rather than applying the binary distinction between natural and un-natural this debate is interesting for our question because it helps to study how these cognitive conditions relate to the plasticity of cultural processes, and how knowledge modes in both fields - believing, questioning, reflecting - can be compared in surprising ways.

A last, crucial, aspect of understanding the entangled process of differentiation between religion, science, art and aesthetics has not been adequately addressed yet, and it can only be sketched here as a field for further research. It relates to the work presented in section 2, the 'double pluralism' in European history and the interaction between the sub-spheres of society that could only develop because of their differentiation into autonomous spheres. The roots of today's entanglement can be identified in the longue durée of romanticism, an era that saw both the differentiation process and the attempt to find new grounds to merge and relate the emerging societal sub-systems in order to keep a general and binding framework for European culture alive (on a genealogy of the 'possibility of romantic science' see Halliwell 2016). In contrast to the alleged unimportance of aesthetics as a mere cultural surplus, or as a cultivated decoration of an otherwise settled and sorted bourgeois existence, we need to understand the rise of aesthetics - and the massive aestheticisation of a capitalist modernity (Reckwitz 2017, Featherstone 1992) - as an 'aesthetic revolution' (Vietta 2008) that is interconnected with those developments that have led to the individualistic, self-referential and reflexive 'modern subject' we are re-thinking today. These developments can roughly be named as the eighteenth-century development of a science of the senses, the nervous system and the human brain (physiology and psychology); the religious development of the 'inner human being' in Protestantism; and the emancipation of art from religion and of art as a medium for creating and reflect- 
ing emotions (see also Sally Promey's interesting take on Kant's aesthetic as an attempt to de-sacralise yet save religious expressions under the new experiential sphere of autonomous art, Promey 2014: 10).

Without understanding the role of the history of modern religion in relation to art and science, the rejection of, and the engagement with, aesthetics in science is difficult to understand. Romantic art, in this view, reflected the state of knowledge about sensing and feeling, and how these can be evoked; at the same time, the images ask us to identify with the figures and the atmosphere they convey. It is a new way of seeing that is cultivated here; one that does not seek to decode the significance of saints and symbols in the image, but that offers to experience the atmosphere and to identify with moods, feelings and sensations that the images invoke. Romanticism, in its many variations, offers a new mode of religiosity that draws on individual experience rather than a personal God or doctrines. It becomes possible to be 'spiritual but not religious' by practices making art, nature and sensation itself the object and the medium of an experience that equals the inward, transcendent and 'spiritual' quality of a privatised and individualised religiosity that has fitted so well the demands of a secularising modernity. It is this separation between the aesthetic and the scientific, and the spiritualisation of the aesthetic that are still evoked when references are made to beauty in science communication. ${ }^{2}$

\section{Concluding remarks}

On a final note, there is a last aspect we deem to be an important feature of discussions about the aesthetic formation of knowledge, and this is the reflexive potential the contributions in this volume provide us with for our own work. If we want to advance the conversation between different modes of academic knowledge, we need to actively create building blocks (Taves 2015) to communicate knowledge across the disciplines, and this includes reflections on how we know and how we conceptualise the knowing subject, both the scholarly subject and the subjects we study (Koch 2017). Aesthetic aspects of knowing cannot be confined to rational and abstract thinking, either 'in the field' or in analysis. Creating an awareness of how we use images, what imaginative

2 For more details and literature, see Grieser 2015a, and 2017. domains rule our work and what aesthetic ideologies (Grieser 2017) we are supporting are not only questions of didactics or contingent forms. An aesthetic critique adds to the quality of academic analysis if it is seen as a part of the epistemological and methodological rigour which every scholar is expected to apply in logic and argument. Applying the concept of an aesthetics of knowledge, proposed in these pages, as a comparative tool will show that there are more cornerstones to be defined, categories to be identified and mechanisms to be understood. This essay may be seen as a preliminary map that demarcates a few borderlines and locates areas where bridge building would help. It understands itself as an invitation to add to this map.

Arianna Borrelli is a historian and philosopher of natural philosophy and modern science. The focus of her research is the relationship between scientific knowledge and the strategies employed to communicate, store and transform it. Her specific fields of interest include medieval mathematical cosmology, early modern meteorology and optics, and quantum theories from their early days up to the present. She graduated in physics at Rome University and in philosophy and history at the University of Braunschweig, where she subsequently took a PhD in the history of science. She held research positions in theoretical high-energy physics and in the history and philosophy of science in Italy, Switzerland, Great Britain and Germany. She is currently working at the Technische Universität Berlin on a project funded by the German Research Council (DFG) on concept formation in early particle physics (1950-65) (DFG Project-Nr. BO 4062/2-1). Her main publications include: 'From Logos to Mythos: narratives of "naturalness" in today's particle physics community' in Narrated Communities: Narrated Realities, H. Blume and C. Leitgeb (2015), pp. 69-83; 'Thinking with optical objects: glass spheres, lenses and refraction in Giovan Battista Della Porta's optical writings', Journal of Early Modern Studies, 3 (2014): 38-60; Aspects of the Astrolabe: 'Architectonica Ratio' in Tenth- and Eleventhcentury Europe (Franz Steiner Verlag 2008).

Alexandra Grieser is Assistant Professor for the Theory of Religion at Trinity College, Dublin. She is trained in the Study of Religion, German Literature and Rhetoric (University of Tuebingen). She held positions at the University of Bremen, at the LMU Munich and at the University of Groningen (The Netherlands).

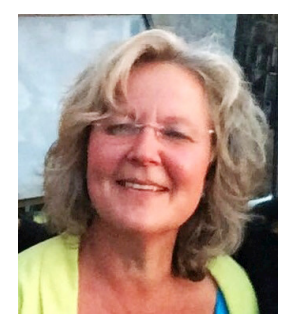
Her research focuses on method and theory in the study of religion; European pluralism; the history and theory of knowledge; religion and rhetoric; and the aesthetics of 
religion. She is a founding member of the working group for the aesthetics of religion (German Association for the Study of Religion) and a member of the research network AESToR NET. She has published a monograph on changing plausibility patterns in modern religion (Transformations of Immortality, Peter Lang 2008), articles and book chapters on fascination as an aesthetic strategy; on museality as a matrix of knowledge production, and on the popular aesthetics of Hubble Space photography. She is co-editor of the first volume in English on Aesthetics of Religion: $A$ Connective Concept (with Jay Johnston, de Gruyter 2017).

\section{Bibliography}

Adelmann, Ralf, Jan Frercks, Martina Hessler, and Jochen Hennig (eds.), 2009. Datenbilder. Zur digitalen Bildpraxis in den Naturwissenschaften (Bielefeld, transcript)

Alberti, Fay Bound, 2016. This Mortal Coil: The Human Body in History and Culture (Oxford University Press)

Arnheim, Rudolf, 1969. Visual Thinking (Berkeley, University of California Press)

Asprem, Egil, 2014. The Problem of Disenchantment: Scientific Naturalism and Esoteric Discourse 19001939 (Leiden, Brill)

Azzouni, Safia, Stefan Böschen, and Carsten Reinhardt (eds.), 2015. Erzählung und Geltung. Wissenschaft zwischen Autorschaft und Autorität (Weilerswist, Velbrück Wissenschaft)

Bildwelten des Wissens. Jahrbuch für Bildkritik, 2003-17

Blume, Hermann, Christoph Leitgeb, and Michael Rössner (eds.), 2015. Narrated Communities - Narrated Realities: Narration as Cognitive Processing and Cultural Practice (Leiden, Brill | Rodopi)

Böhme, Gernot, 2001. Aisthetik. Vorlesungen über Ästhetik als allgemeine Wahrnehmungslehre (München, Fink)

Borck, Cornelius (ed.), 2013. Hans Blumenberg beobachtet. Wissenschaft, Technik und Philosophie (Freiburg, Alber)

Borrelli, Arianna, 2012. 'The case of the composite Higgs: the model as a "Rosetta stone" in contemporary highenergy physics', Studies in the History and Philosophy of Modern Physics, 43(3), pp. 195-214

-2015a. 'Genesis des Gottesteilchen. Narrativen der Massenerzeugung in der Teilchenphysik' in Erzählung und Geltung. Wissenschaft zwischen Autorschaft und Autorität, eds. Safia Azzouni, Stefan Böschen, and Carsten Reinhardt (Weilerswist, Velbrück Wissenschaft), pp. 63-86

-2015b. 'From Logos to Mythos: "naturalness" in highenergy-physics' in Narrated Communities - Narrated Realities: Narration as Cognitive Processing and Cultural Practice, eds. Hermann Blume and Christoph Leitgeb (Leiden, Brill | Rodopi), pp. 69-83

Bourdieu, Pierre, 1984. Distinction: A Social Critique of the Judgement of Taste (London, Routledge)

Brandt, Christina, 2004. Metapher und Experiment. Von der Virusforschung zum genetischen Code (Göttingen, Wallstein)

-2009. 'Wissenschaftserzählungen. Narrative Strukturen im naturwissenschaftlichen Diskurs' in Wirklichkeitserzählungen: Felder, Formen und Funktionen nichtliterarischen Erzählens, eds. Christian Klein and Matias Martinez (Stuttgart, Metzler), pp. 81-109 Bredekamp, Horst, Vera Dünkel, and Birgit Schneider (eds.), 2015. The Technical Image: A History of Styles in Scientific Imagery (University of Chicago Press)

Breidbach, Olaf (ed.), 1997. Natur der Ästhetik - Ästhetik der Natur. Ästhetik und Naturwissenschaften: Neuronale Ästhetik (Vienna, Springer)

-2005. Bilder des Wissens. Zur Kulturgeschichte der wissenschaftlichen Wahrnehmung (München, Fink)

Brooke, John Hedley, Margaret J. Osler, and Jitse van der Meer (eds.), 2001. Science in Theistic Contexts: Cognitive Dimensions, Osiris 16 (University of Chicago Press)

Brunotte, Ulrike, 2017. 'The performative knowledge of ecstasy: Jane E. Harrison's early contestations of the textual paradigm in religious studies' in Aesthetics of Religion: A Connective Concept, eds. Alexandra Grieser and Jay Johnston (Berlin and Boston, de Gruyter), pp. 161-88

Burri, Regula Valérie, Cornelius Schubert, and Jörg Strübing (eds.), 2011. 'The Five Senses of Science, Special Issue Science, Technology \& Innovation Studies, $7(1)<$ http://www.sti-studies.de/ojs/index.php/sti/ article/view/56>

Bynum, William F., and Roy Porter (eds.), 1994. Medicine and the Five Senses (Cambridge University Press)

Cartwright, Nancy, Stathis Psillos, and Hasok Chang, 2003. 'Theories of scientific method: models for the physico-mathematical sciences' in The Cambridge History of Science, vol. 5: The Modern Physical and Mathematical Sciences, ed. Mary Jo Nye (Cambridge University Press), pp. 21-35

Cazeaux, Clive (ed.), 2011. The Continental Aesthetics Reader, 2nd edn (London, Routledge)

Chevalley, Catherine, 1996. 'Physics as an art: the German tradition and the symbolic turn in philosophy, history of art and natural science in the 1920s' in The Elusive Synthesis: Aesthetics and Science, ed. Alfred I. Tauber (Dordrecht, Springer), pp. 227-49

Classen, Constance (ed.), 2014. A Cultural History of the Senses, vols. 1-6 (London, Bloomsbury)

Coopmans, Caroline, Steve Woolgar, Michael Lynch, and Janet Vertesi (eds.), 2014. Representation in Scientific Practice Revisited (Cambridge, MA, The MIT Press)

Daston, Lorraine, and Katharine Park, 2001. Wonders and the Order of Nature: 1150-1750 (New York, Zone Books)

Daston, Lorraine, and Peter Galison, 2007. Objectivity (New York, Zone Books)

Daum, Andreas, 2002. Wissenschaftspopularisierung im 19. Jahrhundert. Bürgerliche Kultur, naturwissenschaftliche Bildung und die deutsche Öffentlichkeit, 1848-1914, 1st edn 1998, 2nd enlarged paperback edn (Munich, Oldenbourg)

De Regt, Henk W., 2002. 'Beauty in physical science circa 2000', International Studies in 
the Philosophy of Science, 16(1), pp. 95-103

<doi:10.1080/02698590120118855>

Derrida, Jacques, 1967. De la grammatologie (Paris, Ed. Minuit)

Doxiadēs, Apostolos K., and Barry Mazur (eds.), 2012. Circles Disturbed: The Interplay of Mathematics and Narrative (Princeton University Press)

Eagleton, Terry, 1990. The Ideology of the Aesthetic (Oxford, Blackwell)

Elkins, James, and Harper Montgomery (eds.), 2013. Beyond the Aesthetic and the Anti-Aesthetic (University Park, PA, Penn State University Press)

Engelke, Matthew, 2007. A Problem of Presence: Beyond Scripture in an African Church (Berkeley, University of California Press)

Featherstone, Mike, 1992. 'Postmodernism and the aestheticization of everyday life' in Modernity and Identity, eds. Scott Lash and Jonathan Friedman (Oxford, Blackwell), pp. 265-90

Ferngren, Gary B., Edward J. Larson, and Darrel W. Amundsen (eds.), 2000. The History of Science and Religion in the Western Tradition: An Encyclopedia (New York, Garland Publishing)

Feyerabend, Paul, 1975. Against Method: Outline of an Anarchistic Theory of Knowledge (London, Humanities Press)

Fleck, Ludwig, 1935. Entstehung und Entwicklung einer wissenschaftlichen Tatsache. Einführung in die Lehre vom Denkstil und Denkkollektiv (Frankfurt am Main, Suhrkamp)

Flusser, Vilém, 1983. Für eine Philosophie der Fotografie (Göttingen, European Photography)

Frappier, Mélanie, Letitia Meynell, and James Robert Brown (eds.), 2013. 'Visual representations and reasoning', Special Issue The Knowledge Engineering Review, 28(3) <doi:10.1017/So269888913000362>

Frigg, Roman, and James Nguyen, 2016. 'Scientific representation' in The Stanford Encyclopedia of Philosophy, ed. Edward N. Zalta <https://plato.stanford.edu/ archives/win2016/entries/scientific-representation/> (accessed 15.8.17)

Galison, Peter, 1997. Image and Logic: A Material Culture of Microphysics (University of Chicago Press)

Geertz, Armin (ed.), 2014. Origins of Religion, Cognition and Culture (Milton Park, Routledge)

Gell, Alfred, 1998. Art and Agency (Oxford University Press)

Ginsberg, Alexandra Daisy, 2012. 'Sensation: in search of aesthetic experience in chemical biology', Current Opinion in Chemical Biology, 16(5), pp. 553-56 <doi:10.1016/j.cbpa.2012.11.003>

Gladigow, Burhard, 1995. 'Europäische Religionsgeschichte' in Lokale Religionsgeschichte, eds. Hans G. Kippenberg and Brigitte Luchesi (Marburg, Diagonal), pp. 71-92

Golinski, Jan, 2005. Making Natural Knowledge: Constructivism and the History of Science (University of Chicago Press)

Gooding, David, Trevor Pinch, and Simon Schaffer (eds.),
1989. The Uses of Experiment: Studies in the Natural Sciences (Cambridge University Press)

Göttler, Christine, and Wolfgang Neuber (eds.), 2007. Spirits Unseen: The Representation of Subtle Bodies in Early Modern European Culture (Leiden, Brill)

Graduate School 1662. Graduiertenkolleg 1662 Religiöses Wissen im vormodernen Europa (800-1800), Eberhard Karls Universität Tübingen, DFG funded $<$ http://www.uni-tuebingen.de/en/research/coreresearch/research-training-groups/gk-religioeseswissen.html > (accessed 15.10.2017)

Grieser, Alexandra, 2015a. 'Imaginationen des Nichtwissens. Zur Hubble Space Imagery und den Figurationen des schönen Universums zwischen Wissenschaft, Kunst und Religion' in Religion - Imagination - Ästhetik. Vorstellungs- und Sinneswelten in Religion und Kultur, eds. Annette Wilke and Lucia Traut (Göttingen, Vandenhoek \& Ruprecht)

-2015b. 'Aesthetics' in Vocabulary for the Study of Religion, vol. 1, eds. Kocku von Stuckrad and Robert Segal (Leiden, Brill), pp. 14-23

-2015c. 'Rhetoric' in Vocabulary for the Study of Religion, vol. 3, eds. Kocku von Stuckrad and Robert Segal (Leiden, Brill), pp. 227-34

-2017. 'Blue brains: knowledge formation and aesthetic ideologies between religion and science' in Aesthetics of Religion: A Connective Concept, eds. Alexandra Grieser, and Jay Johnston (Berlin and Boston, de Gruyter), pp. 237-70

Grieser, Alexandra, and Jay Johnston, 2017. 'What is an aesthetics of religion? From the senses to meaning and back again' in Aesthetics of Religion: A Connective Concept, eds. Alexandra Grieser and Jay Johnston (Berlin and Boston, de Gruyter), pp. 1-51

Gross, Alan G., 1990. The Rhetoric of Science (Cambridge, MA, Harvard University Press)

-2006. Starring the Text: The Place of Rhetoric in Science Studies (Carbondale, Southern Illinois UP)

Hacking, Ian, 1983. Representing and Intervening: Introductory Topics in the Philosophy of Natural Science (Cambridge University Press)

Halliwell, Martin, 2016. Romantic Science and the Experience of the Self: Transatlantic Crosscurrents from William James to Oliver Sacks (London, Routledge)

Halpern, Orit, 2014. Beautiful Data: A History of Vision and Reason since 1945 (Durham, Duke University Press)

Hammer, Olav, 2004. Claiming Knowledge: Strategies of Epistemology from Theosophy to the New Age (Leiden, Brill)

Hammer, Olav, and James R. Lewis (eds.), 2011. Handbook of Religion and the Authority of Science (Leiden, Brill)

Hanegraaff, Wouter J., 2012. Esotericism and the Academy: Rejected Knowledge in Western Culture (Cambridge University Press)

Harris, Randy Allen, 1991. 'Rhetoric of science', College English, 53(3), pp. 282-307

-(ed.), 1997. Landmark Essays on Rhetoric of Science: Case Studies (Mahwah, Hermagoras Press) 
Harrison, Peter, 2015. The Territories of Science and Religion (University of Chicago Press)

Heintz, Bettina, and Jörg Huber (eds.), 2001. Mit dem Auge denken. Strategien der Sichtbarmachung in wissenschaftlichen und virtuellen Welten (Zürich, Voldemeer)

Hessler, Martina, and Dieter Mersch (eds.), 2009a. Logik des Bildlichen. Zur Kritik der ikonischen Vernunft (Bielefeld, transcript)

-2009b. 'Einleitung' in Logik des Bildlichen. Zur Kritik der ikonischen Vernunft, eds. Martina Hessler and Dieter Mersch (Bielefeld, transcript), pp. 8-62

Hinterwaldner, Inge, and Markus Buschhaus (eds.), 2006. The Picture's Image. Wissenschaftliche Visualisierung als Komposit (Munich, Fink)

Houtman, Dick, and Birgit Meyer, 2012. Things: Religion and the Question of Materiality (New York, Fordham UP)

Howes, David, 2014. 'Introduction: "Make it new!" Reforming the sensory world' in A Cultural History of the Senses in the Modern Age, 1920-200o, ed. David Howes (London, Bloomsbury), pp. 1-30

Hoyningen-Huene, Paul, 1987. 'Context of discovery and context of justification', Studies in History and Philosophy of Science, Part A, 18(4), pp. 501-15

Iconoclash Exhibition Website <http://hosting.zkm.de/ icon/stories/storyReader\$3> (accessed 7.9.2017)

Johnson, Mark, 2008. The Meaning of the Body. Aesthetics of Human Understanding (University of Chicago Press)

-2015. 'The aesthetics of embodied life' in Aesthetics and the Embodied Mind: Beyond Art Theory and the Cartesian Mind-Body Dichotomy, ed. Alfonsina Scarinzi (Dordrecht, Springer), pp. 23-38

Johnston, Jay, and Geoffrey Samuel, 2013. Religion and the Subtle Body in Asia and the West: Between Mind and Body (London and New York, Routledge)

Jones, Caroline A., and Peter Galison, (eds.), 1998a. Picturing Science, Producing Art (New York, Routledge)

-1998b. 'Introduction' in Picturing Science, Producing Art, eds. Caroline A. Jones and Peter Galison (New York, Routledge), pp. 1-23

Jütte, Robert, 2014. 'The senses in philosophy and science: from the senses to sensations' in A Cultural History of the Senses in the Age of Empire, ed. Constance Classen (London, Bloomsbury), pp. 113-36

Kay, Lily E., 200o. Who Wrote the Book of Life? A History of the Genetic Code (Stanford University Press)

Kippenberg, Hans G., 2002. Discovering Religious History in the Modern Age, transl. Barbara Harshav (Princeton University Press)

Kittler, Friedrich A., 1995. Aufschreibesysteme 1800, 1900 (Munich, Fink)

Knott, Kim, 2005. The Location of Religion: A Spatial Analysis (London, Equinox)

Koch, Anne, 2011. 'Reasons for the boom of body discourses in the humanities and the social sciences since the 1980s: a chapter in European history of religion' in Menschenbilder und Körperkonzepte, eds.
Angelika Berlejung, Johannes Quack, and Jan Dietrich (Tübingen, Mohr), pp. 3-41

-2016. " "Koerper Wissen” - Koerpermacht' in Para-

grana. Zeitschrift für Historische Anthropologie, Special Issue 'Koerperwissen: Transfer und Innovation', 25(1), pp. $61^{-7} 75$

-2017. 'The governance of aesthetic subjects through body knowledge and affect economies: a cognitiveaesthetic approach' in Aesthetics of Religion: A Connective Concept, eds. Alexandra Grieser and Jay Johnston (Berlin and Boston, de Gruyter), pp. 389-412

Krämer, Sybille, 2016. Figuration, Anschauung, Erkenntnis. Grundlinien einer Diagrammatologie (Berlin, Suhrkamp)

Krohn, Wolfgang (ed.), 2006. Ästhetik in der Wissenschaft. Interdisziplinärer Diskurs über das Gestalten und Darstellen von Wissen (Hamburg, Meiner)

Kugele, Jens, and Katharina Wilkens (eds.), 2011. 'Relocating religion(s): museality as a critical term for the aesthetics of religion, Journal of Religion in Europe, Special Issue, 4(1), pp. 7-13

Kuhn, Thomas S., 1962. The Structure of Scientific Revolutions (Chicago University Press)

Lakoff, George, 1999. Philosophy in the Flesh: The Embodied Mind and Its Challenge to Western Thought (New York, Basic Books)

Lakoff, George, and Mark Johnson, 1980. Metaphors We Live By (University of Chicago Press)

Lakoff, George, and Rafael E. Núñez, 200o. Where Mathematics Comes From: How the Embodied Mind Brings Mathematics into Being (New York, Basic Books)

Latour, Bruno, 1990. 'Drawing things together' in Representation in Scientific Practice, eds. Michael Lynch and Steve Woolgar (Cambridge, MA, MIT Press), pp. 19-68

Latour, Bruno, and Peter Weibel (eds.), 2002. Iconoclash (Cambridge, MA, MIT Press)

Latour, Bruno, and Steve Woolgar, 1986. Laboratory Life: The Social Construction of Scientific Facts (Princeton University Press)

Lenoir, Timothy (ed.), 1998. Inscribing Science: Scientific Texts and the Materiality of Communication (Stanford University Press)

Lynch, Michael, 1988. 'The externalized retina: selection and mathematization in the visual documentation of objects in the life sciences', Human Studies, 11(2-3), pp. 201-34 <doi:10.1007/BFo0177304>

Lynch, Michael, and Samuel Y. Edgerton, 1996. 'Abstract painting and astronomical image processing' in The Elusive Synthesis: Aesthetics and Science, ed. Alfred I. Tauber (Dordrecht, Springer), pp. 103-24

Lynch, Michael, and Steve Woolgar, 1988. 'Introduction: sociological orientations to representational practice in science' Human Studies, 11(2-3), pp. 99-116, reprinted in Representation in Scientific Practice, eds. Michael Lynch and Steve Woolgar (Cambridge, MA, MIT Press)

-(eds.), 1990. Representation in Scientific Practice (Cambridge, MA, MIT Press) 
Mandoki, Katya, 2007. Everyday Aesthetics: Prosaics, the Play of Cultures and Social Identities (Aldershot, Ashgate)

Maslen, Sarah, 2015. 'Researching the senses as knowledge: a case study of learning to hear medically', The Senses \& Society, 10(1), pp. 52-70

McAllister, James W., 1989. 'Truth and beauty in scientific reason', Synthese, 78(1), pp. 25-51

-1990 . 'Dirac and the aesthetic evaluation of theories', Methodology and Science, 23, pp. 87-102

-1996. 'Scientists' aesthetic preferences among theories: conservative factors in revolutionary crises' in The Elusive Synthesis: Aesthetics and Science, ed. Alfred I. Tauber (Dordrecht, Springer), pp. 169-87

-(ed.), 2002. 'Recent work on aesthetics of science', International Studies in the Philosophy of Science, 16(1) <doi:10.1080/02698590120118783>

-2013. 'Reasoning with visual metaphors', The Knowledge Engineering Review, 28(3), pp. 367-79 <doi:10.1017/ So269888913000295>

McCauley, Robert N., 2012. Why Religion is Natural and Science is Not (Oxford University Press)

McLuhan, Marshall, 1965. Understanding Media: The Extensions of Man, critical edition, 1st edn 1964 (Corte Madera, Gingko Press)

Menninghaus, Winfried, 2011. Wozu Kunst? Ästhetik nach Darwin (Berlin, Suhrkamp)

Menninghaus, Winifred, Valentin Wagner, Julian Hanich, Eugen Wassiliwizky, Milena Keuhnast, and Thomas Jacobsen, 2015. 'Towards a psychological construct of being moved, PLoS ONE, 10(6), e0128451 $<$ doi:10.1371/journal.pone.0128451>

Meyer, Stephen C., 2000. 'The demarcation of science and religion' in The History of Science and Religion in the Western Tradition: An Encyclopedia, eds. Gary B. Ferngren, Edward J. Larson, and Darrel W. Amundsen (New York, Garland Publishing), pp. 18-26

Miller, Arthur I., 1986. Imagery in Scientific Thought: Creating 2oth-Century Physics (Cambridge, MA, MIT Press)

Mohr, Hubert, 2005. 'Perception / sensory system' in The Brill Dictionary of Religion, vol. 3, ed. Kocku von Stuckrad (Leiden, Brill), pp. 1435-48

Moore, James R., 1992. 'Speaking of "science and religion" - then and now', History of Science, 30, pp. 311-23

Morus, Iwan Rhys, 2011. Shocking Bodies: Life, Death \& Electricity in Victorian England (Stroud, History Press)

Nudds, Matthew, 2014. 'The senses in philosophy and science: from sensation to computation' in A Cultural History of the Senses in the Modern Age, 1920-200o, ed. David Howes (London, Bloomsbury), pp. 125-47

Nye, Mary Jo, 2003. 'Introduction: the modern physical and mathematical sciences' in The Cambridge History of Science, vol. 5, The Modern Physical and Mathematical Sciences, ed. Mary Jo Nye (Cambridge University Press), pp. 1-17

Paragrana. Zeitschrift fuer Historische Anthropologie, Special Issue 'Koerperwissen: Transfer und Innovation', 25(1), 2016, pp. 61-75
Pauwels, Luc (ed.), 2006. Visual Cultures of Science: Rethinking Representational Practices in Knowledge Building and Science Communication (Hanover, NH, University Press of New England)

Pickering, Andrew, 1995. The Mangle of Practice: Time, Agency, and Science (University of Chicago Press)

Polanyi, Michael, 1958. Personal Knowledge: Towards a Post-critical Philosophy (London, Routledge and Kegan Paul)

-1966. The Tacit Dimension (University of Chicago Press)

Promey, Sally M. (ed.), 2014. Sensational Religion: Sensory Cultures in Material Practice (New Haven, Yale University Press)

Rancière, Jacques, 2010. The Politics of Aesthetics: The Distribution of the Sensible (London, Continuum)

Reckwitz, Andreas, 2006. Das hybride Subjekt. Eine Theorie der Subjektkulturen von der bürgerlichen Moderne zur Postmoderne (Weilerswist, Velbrück Wiss)

-2017 (2012). The Invention of Creativity: Modern Society and the Culture of the New, transl. Steven Black (Cambridge, Polity)

Roberts, Lissa, 2014. 'The senses in philosophy of science' in A Cultural History of the Senses in the Age of Enlightenment, ed. Anne C. Vila (London, Bloomsbury), pp. 109-31

Rorty, Richard, 1979. Philosophy and the Mirror of Nature (Princeton University Press)

Ross, Andrew, 1996. Science Wars (Durham, Duke University Press)

Rotman, Brian, 1993. Ad infinitum: The Ghost in Turing's Machine. Taking God Out of Mathematics and Putting the Body Back in ... an Essay in Corporeal Semiotics (Stanford University Press)

Rusch, Hannes, and Eckart Voland, 2013. 'Evolutionary aesthetics: an introduction to key concepts and current issues', Aisthesis, 6(2), pp. 113-33

Schaffer, Simon, John Tresch, and Pasquale Gagliardi (eds.), 2017. Aesthetics of Universal Knowledge (Cham, Springer)

Schickore, Jutta (ed.), 2006. Revisiting Discovery and Justification: Historical and Philosophical Perspectives on the Context Distinction (Dordrecht, Springer)

-2017. 'Geschichte und Philosophie der Wissenschaften' in Handbuch Wissenschaftsgeschichte, eds. Marianna Sommer, Staffan Müller-Wille, and Carsten Reinhardt (Stuttgart, J.B. Metzler Verlag), pp. 20-32

Scarinzi, Alfonsina (ed.), 2015. Aesthetics and the Embodied Mind: Beyond Art Theory and the Cartesian MindBody Dichotomy (Dordrecht, Springer

Schrempp, Gregory, 2012. The Ancient Mythology of Modern Science: A Mythologist Looks (Seriously) at Popular Science Writing (Montréal, McGill-Queen's University Press)

-2016. The Science of Myths and Vice Versa (Chicago, Prickly Paradigm Press)

Shapin, Steven, and Simon Schaffer, 1985. Leviathan and the Air-Pump: Hobbes, Boyle, and the Experimental Life (Princeton University Press) 
Shusterman, Richard (ed.), 1989. Analytic Aesthetics (Oxford, Blackwell)

-2012. Thinking through the Body: Essays in Somaesthetics (Cambridge University Press)

Smith, Mark M., 2007. Sensing the Past: Seeing, Hearing, Smelling, Tasting, and Touching in History (Berkeley, University of California Press)

Smith, Pamela H., 2012. The Body of the Artisan: Art and Experience in the Scientific Revolution (University of Chicago Press)

Steinle, Friedrich, 2009. 'Naturwissenschaft', in Enzyklopädie der Neuzeit, ed. Friedrich Jaeger <http://dx.doi. org/10.1163/2352-0248_edn_a2955000> (accessed 24.10.2017)

Stolow, Jeremy (ed), 2013. Deus in Machina: Religion, Technology, and the Things in Between (New York, Fordham University Press)

Stuckrad, Kocku von, 2010. Locations of Knowledge in Medieval and Early Modern Europe: Esoteric Discourse and Western Identities (Leiden, Brill)

-2014. The Scientification of Religion: An Historical Study of Discursive Change, 180o-200o (Berlin, de Gruyter)

Tauber, Alfred I. (ed.), 1996. The Elusive Synthesis: Aesthetics and Science (Dordrecht, Springer)

Taves, Ann, 2015. 'Reverse engineering complex cultural concepts: identifying building blocks of "religion", Journal of Cognition and Culture, 15, pp. 191-216

Traut, Lucia, and Annette Wilke (eds.), 2015. Religion Imagination - Ästhetik. Vorstellungs- und Sinneswelten in Religion und Kultur (Göttingen, Vandenhoeck \& Ruprecht)

Tresch, John, 2017. 'Cosmopragmatics and petabytes' in Aesthetics of Universal Knowledge, eds. Simon Schaffer, John Tresch, and Pasquale Gagliardi (Cham, Springer), pp. $137^{-56}$

Turnbull, David, and Helen Watson, 1989. Maps are Territories, Science is an Atlas: A Portfolio of Exhibits (Geelong, Deakin University Press)

Turner, Mark, and Gilles Fauconnier, 2002. The Way We Think: Conceptual Blending and the Mind's Hidden Complexities (New York, Basic Books)

Van de Port, Matthijs, 2011. '(Not) made by the human hand: media consciousness and immediacy in the cultural production of the real', Social Anthropology, Special Issue: What is a Medium? Theologies, Technologies and Aspirations, 19(1), pp. 74-89

Varela, Francisco J., Evan Thompson, and Eleanor Rosch (eds.), 1996. The Embodied Mind: Cognitive Science and Human Experience (Cambridge, MA, MIT Press)

Vietta, Silvio, 2008. 'Die Ästhetikrevolution um 1800' in Special Issue of Deutsch-russische Germanistik. Ergebnisse, Perspektiven und Desiderate der Zusammenarbeit, eds. Dirk Kemper and Iris Bäcker, pp. 151-60

Wehling, Peter, 2015. Vom Nutzen des Nichtwissens. Sozial- und kulturwissenschaftliche Perspektiven (Bielefeld, transcript)

Welsch, Wolfgang, 1987. Aisthesis. Grundzüge und Perspektiven der Aristotelischen Sinneslehre (Stuttgart, Klett-Cotta)
-2014. Aesthetics and Beyond (Kaifeng, Henan University Press)

Wilke, Annette, and Oliver Moebus, 2011. Sound and Communication: An Aesthetic Cultural History of Sanskrit Hinduism, Religion and Society, 41 (Berlin, de Gruyter) 